\title{
Spatial Organization of AMPAR Subtypes in ON RGCs
}

\author{
Rebecca S. Jones, ${ }^{1}$ Marina Pedisich, ${ }^{1}$ Reed C. Carroll, ${ }^{1}$ and Scott Nawy ${ }^{1,2}$ \\ ${ }^{1}$ Dominick P. Purpura Department of Neuroscience and ${ }^{2}$ Department of Ophthalmology and Visual Sciences, Albert Einstein College of Medicine, The Rose \\ F. Kennedy Center, Bronx, New York 10461
}

Retinal ganglion cells (RGCs) receive glutamatergic input from bipolar cells through NMDA- and AMPA-type glutamate receptors. Both GluA2-containing, $\mathrm{Ca}^{2+}$-impermeable AMPA receptors (CI-AMPARs) and GluA2-lacking, $\mathrm{Ca}^{2+}$-permeable AMPA receptors (CPAMPARs) contribute to light-evoked responses in ON RGCs; however, specific roles for each subtype are not well understood. Here, we present evidence that light intensity determines the subtype of AMPAR that is activated during the synaptic response in ON RGCs. Using current voltage analysis of the EPSC we show that light intensities near RGC threshold, intensities that travel through the well described primary rod pathway, evoke synaptic currents that are preferentially mediated by CP-AMPARs. Synaptic responses evoked by spontaneous release of transmitter from bipolar cell terminals also preferentially activate CP-AMPARs. Conversely, higher light intensities, most likely carried by secondary rod pathways, activate CI-AMPARs. The same pattern of CP-AMPAR and CI-AMPAR activation was observed in mice containing only functional rods, suggesting that the recruitment of CI-AMPARs at higher light intensity does not require cone stimulation. When glutamate spillover was induced by blocking transporters with TBOA, both the near threshold and spontaneous EPSCs contained a significant CI-AMPAR component. We propose that CI-AMPARs are activated by "spillover" of synaptic glutamate only during bright illumination, or when glutamate uptake is blocked. Glutamate may spill over to more distant sites at the same synapse, or perhaps as far as neighboring synapses. Together, our data suggest that the spatial organization of AMPARs at ON RGCs synapses allows for selective, intensity-dependent activation of AMPARs with distinct subunit composition.

\section{Introduction}

In the mammalian retina, there are at least two circuits that convey rod input to ganglion cells. In one, the primary pathway, rods synapse onto a type of ON bipolar cell called the rod bipolar cell, which in turn makes a synapse onto the AII amacrine cell (Kolb and Famiglietti, 1974; Strettoi et al., 1990; Mills and Massey, 1995). A gap junction connects the AII amacrine cell with the presynaptic terminal of cone-driven $\mathrm{ON}$ bipolar cells, providing for the entry of rod signals into the cone pathway. In the secondary pathway, rod signals are passed into the cones via a gap junction, and are then conveyed to ganglion cells, much in the same way that input originating from cone phototransduction would be conveyed (Smith et al., 1986). ON cone bipolar cells in turn contact $\mathrm{ON}$-type retinal ganglion cells (ON RGCs) (Wässle and Boycott, 1991). This synapse is the final common pathway for both rod and cone signals to ON RGCs (Kolb and Famiglietti, 1974). It is thought that the primary rod pathway carries signals near rod threshold, while the secondary pathway is activated at higher, mesopic light intensities.

Postsynaptic to ON cone bipolar cells, ON RGC glutamate receptors are segregated such that AMPA receptors (AMPARs)

Received March 15, 2013; revised Nov. 18, 2013; accepted Nov. 26, 2013.

Author contributions: R.S.J., R.C.C., and S.N. designed research; R.S.J. and M.P. performed research; R.S.J. and S.N. analyzed data; R.S.J., R.C.C., and S.N. wrote the paper.

This research was supported by National Eye Institute Grant EY017428 (S.N.), and an unrestricted grant from Research to Prevent Blindness (S.N.).

The authors declare no competing financial interests.

Correspondence should be addressed to Scott Nawy, Albert Einstein College of Medicine, Kennedy 525, 1410

Pelham Parkway, Bronx, NY 10461. E-mail: scott.nawy@einstein.yu.edu.

R.C. Carroll's present address: Department of Biology, New Jersey City University, Jersey City, NJ 07305-1597.

DOI:10.1523/JNEUROSCI.1140-13.2014

Copyright $\odot 2014$ the authors $\quad 0270-6474 / 14 / 340656-06 \$ 15.00 / 0$ are flanked by perisynaptic NMDA receptors (NMDARs) (Sagdullaev et al., 2006; Zhang and Diamond, 2006, 2009). Both $\mathrm{Ca}^{2+}$-permeable, GluA2-lacking AMPARs (CP-AMPARs), and $\mathrm{Ca}^{2+}$-impermeable, GluA2-containing AMPARs (CI-AMPARs) are expressed at this synapse (Peng et al., 1995; Qin and Pourcho, 1996, 1999; Grünert et al., 2002; Lin et al., 2002; Xia et al., 2006, 2007; Zhang and Diamond, 2006; Jones et al., 2012). Furthermore, activation of perisynaptic NMDARs either by light or chemically induced ON bipolar cell depolarization, triggers a CIAMPAR to CP-AMPAR switch at this synapse (Jones et al., 2012).

Here we examine the contribution of CI-AMPARs and CPAMPARs to ON RGC light responses and uncover a distinct division of labor between the two classes of AMPARs. Signals carried by the primary rod pathway evoke EPSCs generated primarily by CP-AMPAR activation. This was also true for spontaneous EPSCs (sEPSCs). On the other hand, signals carried by mesopic light, most likely through the secondary pathway, activated predominantly CI-AMPARs. As the primary and secondary rod pathways have been proposed to converge at the ON cone bipolar-ON RGC synapses, our data suggest a spatial segregation of AMPARs. To account for this segregation, we propose two models. In the first, both forms of AMPAR are expressed at all synapses, but CP-AMPARs are positioned closer to the site of transmitter release. In the second model, CP-AMPAR and CIAMPARs are expressed at separate synapses, mediating input from the primary and secondary rod pathway, respectively.

\section{Materials and Methods}

Whole-mount preparation. General aspects of these procedures have been described in detail previously (Jones et al., 2012). All procedures were in accordance with the animal care guidelines for Albert Einstein College of 
Medicine. Four- to six-week-old C57BL/6 (Charles River) and 8-weekold Gnat2 ${ }^{\text {(cpfl3) }}$ mice (The Jackson Laboratory) of both sexes were used in this study. Mice were dark adapted for $1 \mathrm{~h}$ before anesthetizing with isoflurane (Sigma-Aldrich) and cervical dislocation. Dissection was performed under dim red light and retinas were bathed in oxygenated $(95 \%$ $\mathrm{O}_{2}$ and $5 \% \mathrm{CO}_{2}$ ) Ames media (Sigma-Aldrich) at room temperature. Eyes were enucleated and whole retinas were removed, cut in half, and flat mounted ganglion cell layer up onto acetate/nitrate membrane filter paper (Millipore) with a $1.5 \mathrm{~mm}$ hole in the center to allow light to pass through. In the recording chamber retina pieces were superfused with oxygenated Ames at a rate of $4-6 \mathrm{ml} / \mathrm{min}$.

Electrophysiology. The retina was viewed on a video monitor using infrared illumination and a CCD camera (COHU Electronics) mounted to a Zeiss Axioskop microscope equipped with a water-immersion $40 \times$ objective. $\alpha$ ON RGCs were targeted for patch-clamp recordings using established criteria (Dunn et al., 2006). Pipettes (tip resistance 3-5 M $\Omega$; World Precision Instruments) were filled with a cesium gluconate solution containing the following (in $\mathrm{mm}$ ): $123 \mathrm{Cs}$ gluconate, $8 \mathrm{NaCl}, 1 \mathrm{CaCl}_{2}$, 10 EGTA, 10 HEPES, 10 glucose, 5 ATP, 0.4 GTP, and 100-500 $\mu \mathrm{M}$ spermine ( $\mathrm{pH} 7.3 ; 290 \mathrm{mOsm})$. To isolate the AMPAR-mediated EPSC, strychnine $(1 \mu \mathrm{M})$, TPMPA $(50 \mu \mathrm{M})$, picrotoxin $(50 \mu \mathrm{M})$, tetrodotoxin $(0.1 \mu \mathrm{M})$, and either (RS)-CPP $(20 \mu \mathrm{M})$ or D-AP5 $(50 \mu \mathrm{M})$ were added to Ames media. In some experiments philanthotoxin (PhTX, $5 \mu \mathrm{M}$ ) was also included. All chemicals were purchased from Sigma-Aldrich or Tocris Bioscience. Cells were voltage clamped at $-60 \mathrm{mV}$. Holding potentials were corrected for a $-10 \mathrm{mV}$ junction potential, but series resistance, typically measuring $8-20 \mathrm{M} \Omega$, was not compensated for. Recordings were discarded if series resistance was $>20 \mathrm{M} \Omega$.

Light stimulation. Light stimulation was provided by a $20 \mathrm{~W}$ halogen lamp focused through a $40 \times$ objective. An interference filter (peak transmittance at $500 \mathrm{~nm}$ ) and neutral density filters were inserted in the light path to control the intensity and wavelength of light stimulation, and a shutter (Uniblitz; Vincent Associates) was used to control the duration of the stimulation, typically $10 \mathrm{~ms}$. The intensity of the unattenuated light flash was measured to be $4.9 \times 10^{4} \mathrm{R}^{\star} / \mathrm{rod}$ at $500 \mathrm{~nm}$, assuming a collecting area of $0.5 \mu \mathrm{M}$ per rod (Field and Rieke, 2002).

Analysis. Recordings were obtained with an Axopatch 1D using AxoGraph acquisition software and digitized with an ITC-18 interface (Heka Instruments). Analysis was performed using AxoGraph X and KaleidaGraph (Synergy Software) software. To measure the AMPAR rectification index (RI) we first recorded the $I-V$ relationship of the AMPA-mediated light response to a $10 \mathrm{~ms}$ light flash at the indicated light intensity at holding potentials of $-60,0$, and $+40 \mathrm{mV}$. The RI was calculated as the ratio of the measured and predicted EPSC amplitude at $+40 \mathrm{mV}$ such that 1.0 represents the absence of rectification. The predicted EPSC amplitude was obtained from linear extrapolation of the $I-V$ slope between -60 and $0 \mathrm{mV}$. Statistical significance was determined using paired Student's $t$ test. Error bars indicate the SEM and all values are expressed as mean \pm SEM.

\section{Results}

\section{Light-evoked EPSCs reveal spatial organization of} AMPAR subtypes

Our lab has previously reported that ON RGCs express CPAMPARs and CI-AMPARs, and that both receptor types mediate light-evoked EPSCs (Xia et al., 2006, 2007; Jones et al., 2012). However, it is not known if both types of AMPARs are activated at all light intensities, or whether selective AMPAR activation can be achieved. We added to the recording solution the polyamine spermine (100-500 $\mu \mathrm{M})$, an intracellular blocker of CP-AMPARs at positive membrane voltages (Dingledine et al., 1999). CP-AMPAR I-V relationships are characteristically inwardly rectifying due to spermine block, allowing us to determine the contribution of CP-AMPARs versus CI-AMPARs to the light response in recorded RGCs.

We began by characterizing EPSCs evoked by light intensities near RGC threshold, ranging from 0.01 to $0.1 \mathrm{R}^{\star} / \mathrm{rod}$ as in previous studies (Deans et al., 2002; Völgyi et al., 2004; Dunn et al.,

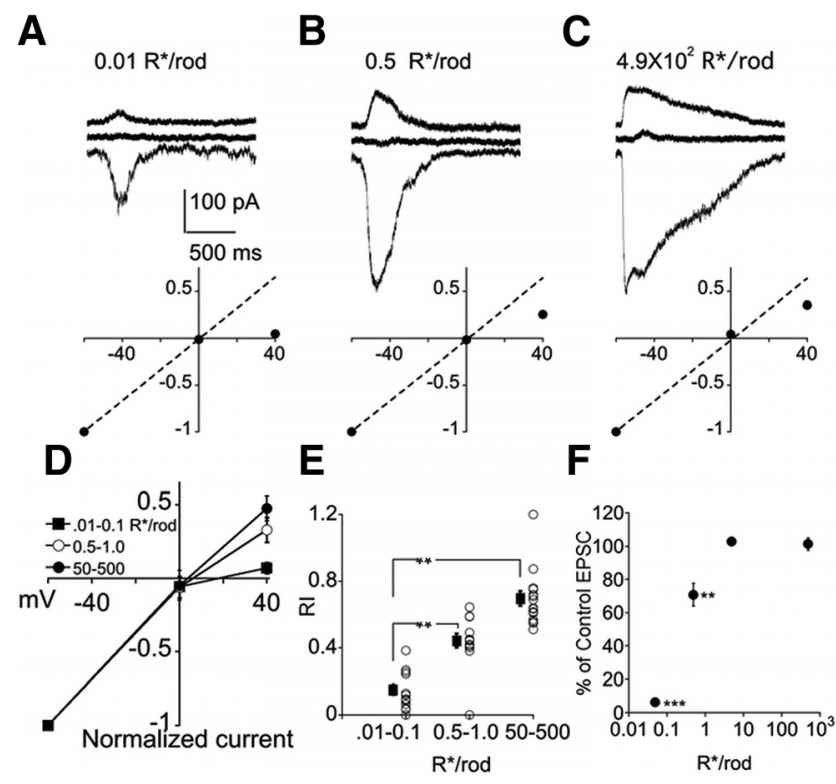

Figure 1. Intensity-dependent activation of AMPAR subtypes. A-C, Top, EPSCs evoked by a $10 \mathrm{~ms}$ light flash at the intensities indicated at holding potentials of $-60,0$, and $40 \mathrm{mV}$. Bottom, Corresponding I-V plots at each light intensity. D, Averaged I-V plots for 13 ON RGCS. Responses have been binned by light intensity as indicated due to variability in flash sensitivity across cells. $\boldsymbol{E}$, Summary of RIs calculated from data in $\boldsymbol{D}$ showing that rectification decreases as the light intensity increases $\left(n=13 ;{ }^{* *} p<0.001\right) . \boldsymbol{F}$, Pooled data summarizing the percentage of inhibition of the light-evoked EPSC PhTX as a function of light intensity $\left(n=6 ;{ }^{* *} p<0.01\right.$, ${ }^{* * *} p<0.001$ vs control).

2006; Wang et al., 2011). EPSCs at this light intensity rectified strongly as shown by the raw data and the corresponding $I-V$ relationship (Fig. 1A), and by the group data (Fig. 1D). The strong rectification in the presence of intracellular spermine indicates that EPSCs evoked by dim light flashes are carried principally by CP-AMPARs. When the light intensity was increased 10-fold to $0.5-1.0 \mathrm{R}^{\star} / \mathrm{rod}$, the resulting EPSC displayed significantly less rectification (Fig. $1 B$ ). To quantify this lightdependent change in rectification, we expressed the $I-V$ relationship at each light intensity as an RI (see Materials and Methods). The RI of the flash response was $0.15 \pm 0.3$ at threshold, and increased to $0.45 \pm 0.04$ at an intensity of $0.5-1.0 \mathrm{R}^{\star} / \mathrm{rod}$ (Fig. $1 C ; n=14 ; p<0.001$ for threshold vs $1 \mathrm{R}^{\star} / \mathrm{rod}$ ). At intensities ranging from 50 to $500 \mathrm{R}^{\star} / \mathrm{rod}$, the $\mathrm{RI}$ increased further to $0.71 \pm 0.04$, a highly significant change compared with both threshold and mesopic light intensities $(p<0.001$ for threshold vs $50-500 \mathrm{R}^{\star} / \operatorname{rod}, p<0.01$ for $1 \mathrm{R}^{\star}$ vs $\left.50-500 \mathrm{R}^{\star} / \mathrm{rod}\right)$.

It is widely accepted that the primary rod pathway mediated by the RBC and AII amacrine cell selectively carries signals near threshold. The sensitivity of the secondary pathway is less clear, but is thought to be approximately $1 \log$ unit less sensitive than the primary pathway (Deans et al., 2002; Völgyi et al., 2004). We exploited the fact that AII amacrine cells express primarily CPAMPARs postsynaptic to RBCs, and blocked this pathway with the CP-AMPAR antagonist PhTX. At RGC threshold, the light response was almost completely blocked in the presence of PhTX (Fig. $1 F ; 6.2 \pm 2.3 \%$ of control, $n=6$ ). This is expected, as CP-AMPARs are expressed on both AII amacrine cells and, as shown above, postsynaptically on RGCs. However, at a light intensity of $0.5 \mathrm{R}^{\star} / \mathrm{rod}$, PhTX inhibited $<50 \%$ of the signal (70.8 \pm $6.9 \%$ of control, $n=6$ ), suggesting that the secondary pathway, which does not use CP-AMPARs for signaling, contributes to transmission of rod signals at this light intensity and can activate 
CI-AMPARs on RGCs. These data are consistent with the idea that the contribution of CI-AMPARs to the light response begins at light intensities that activate the secondary rod pathway, and increases in proportion to light intensity. Interestingly, at higher light intensities, ranging from 5 to $500 \mathrm{R}^{\star} / \mathrm{rod}$, PhTX had essentially no effect on the EPSC amplitude (Fig. 1F; $102.8 \pm 6.9 \%$ of control, $n=6)$. At this light intensity, the rods are capable of signaling (Wang et al., 2011), and so it is unclear why the primary rod pathway does not contribute substantially to the downstream EPSC. One possibility is that synaptic depression at the RBC-AII synapse (Dunn and Rieke, 2008) reduces or eliminates input from the primary rod pathway at mesopic light intensities, making inhibition by PhTX redundant.

The experiments with PhTX described above were performed while inhibition was blocked (see Materials and Methods). To examine the possibility that feedback inhibition onto bipolar cell terminals might prevent activation of postsynaptic CI-AMPARs, even under higher light intensities, we held RGCs at the $-60 \mathrm{mV}$, the reversal potential for inhibitory input and repeated these experiments with inhibition intact. However, we still observed an intensity-dependent switch from CPAMPARs to CI-AMPARs, as PhTX was ineffective at blocking the light response at intensities ranging from 75 to $750 \mathrm{R}^{\star}$ / $\operatorname{rod}(90.2 \pm 8.7 \%$ of control, $n=4)$.

The higher end of the range of light intensities used here would be expected to activate cones, which, despite their relatively few numbers in the mouse retina, strongly drive RGCs under mesopic conditions (Wang et al., 2011). To test the possibility that RGC CI-AMPAR current might be mediated by cones, we recorded from ON RGCs in Gnat $2^{\text {(cplf3) }}$ mice. This mouse line has a mutation in the $\alpha$ subunit of cone transducin (Chang et al., 2006) causing a loss of cone photoreceptor function. Coupling between rods and cones is thought to be unaffected (Altimus et al., 2010), allowing for the transmission of rod signals to cones that constitute the secondary rod pathway. As in wild-type mice, EPSCs recorded near threshold (range 0.005-0.10 $\mathrm{R}^{\star} / \mathrm{rod}$ ) rectified strongly $(\mathrm{RI}=0.14 \pm 0.06, n=9)$, but at an intensity of $500 \mathrm{R}^{\star} / \mathrm{rod}$, rectification was substantially reduced $(\mathrm{RI}=0.70 \pm 0.07, n=9 ; p<$ 0.001 compared with threshold). Thus, intensity-dependent changes in AMPAR subtype activation occur within the primary and secondary rod pathways independent of cone activation. The relationship between light intensity and RI in the Gnat $2^{\text {(cplf3) }}$ mouse line is presented in Figure 2D.

\section{Spillover-activated AMPARs are $\mathrm{Ca}^{2+}$ impermeable}

These results suggest that AMPARs are not randomly distributed, but rather are organized such that CP-AMPARs are more likely to be activated by near threshold stimuli. To test this idea, we blocked glutamate uptake with TBOA, a competitive antagonist of glutamate transporters (Shimamoto et al., 1998) to increase the spread or "spillover" of synaptically released glutamate. Bath application of $10 \mu \mathrm{M}$ TBOA reduced rectification of the threshold response (Fig. $3 A, B$ ). The RI was $0.22 \pm 0.04$ in control conditions, but increased to $0.68 \pm 0.06$ in the presence of TBOA. Similarly, the RI, measured as the ratio of charge transfer at +40 and $-60 \mathrm{mV}$, increased from $0.22 \pm 0.03$ to $0.65 \pm 0.06$ (Fig. $3 C$; $n=4 ; p<0.01$ for both amplitude and charge). The effect of TBOA was not limited to threshold responses as it increased the $\mathrm{RI}$ of EPSCs evoked by flashes containing $5 \mathrm{R}^{\star} /$ rod from $0.61 \pm$ 0.04 (amplitude) and $0.55 \pm 0.07$ (charge), to $1.02 \pm 0.02$ and $0.91 \pm 0.10$, respectively (Fig. $3 D ; n=4, p<0.01$ for amplitude 
A
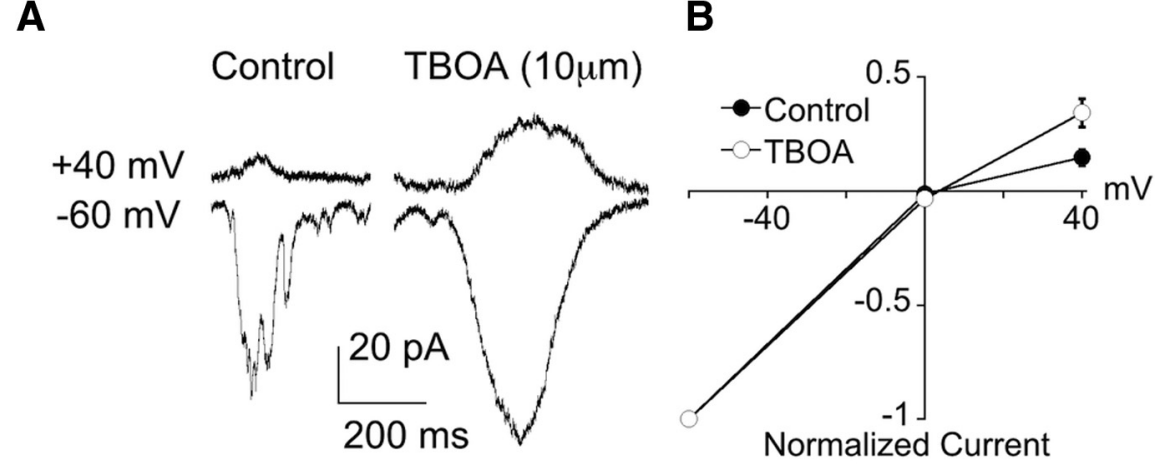

C
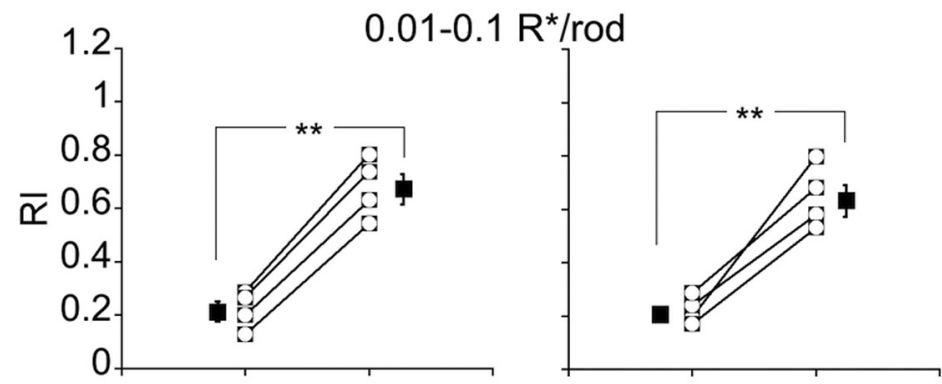

D

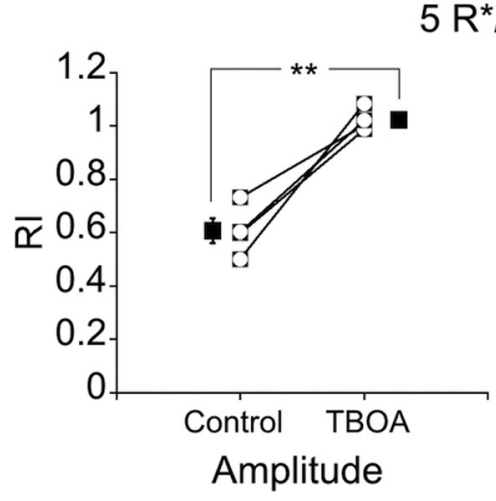

$5 \mathrm{R}^{*} / \operatorname{rod}$

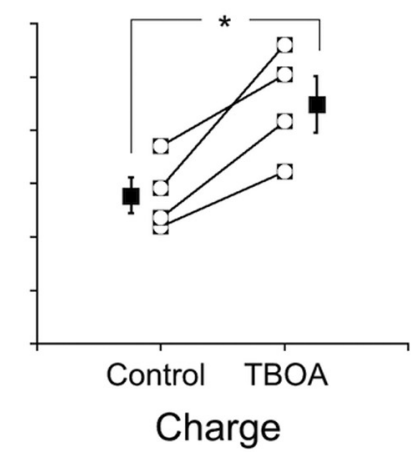

Figure 3. Enhanced spillover activates (I-AMPARs. $\boldsymbol{A}$, Left, EPSC evoked by a dim flash $\left(0.01 \mathrm{R}^{*} / \mathrm{rod}\right)$ in an $\alpha$ ON RGC. Right, For the same light intensity, TBOA increases the amplitude of the current at -60 and $+40 \mathrm{mV}$. B, Average $/-V$ plots for Control and TBOA-treated cells. C, Summary of the effect of TBOA on the RI of dim light flashes. D, As for dim flashes, brighter flashes (5 R* $/ \mathrm{rod}$ ) also show an increase in RI with TBOA application ( $n=4$; ${ }^{* *} p<0.01,{ }^{*} p<0.05$; paired $t$ test).

and $p<0.05$ for charge). These data support the hypothesis that spillover activates a population of AMPARs that are $\mathrm{Ca}^{2+}$ impermeable and are spatially segregated from CP-AMPARs. TBOA elevates the concentration of glutamate in the synaptic cleft, raising the possibility that low-affinity antagonists such as L-APV might be unable to prevent glutamate from binding to NMDARs. Synaptic NMDA currents would also contribute to a linearization of the EPSC due to the relief of $\mathrm{Mg}^{2+}$ block at positive voltages, and could be mistaken for an increased contribution of CIAMPARs. However, this seems unlikely, as we obtained similar results in the presence of $20 \mu \mathrm{M} \mathrm{CPP}$, a high-affinity NMDAR antagonist: TBOA shifted the RI of EPSCs near threshold from $0.17 \pm 0.01$ to $0.71 \pm 0.01$ ( $p=0.009, n=2$; data not shown).

In both mammalian and amphibian ON RGCs spontaneous activity is solely mediated by AMPARs (Taschenberger et al., 1995; Taylor et al., 1995; Matsui et al., 1998; Tian et al., 1998; Chen and Diamond, 2002), consistent with a perisynaptic localization of NMDARs (Zhang and Diamond, 2009). We wondered if these AMPAR sEPSCs are mediated primarily by CP-AMPARs and if increasing spillover might result in activation of CI-
AMPARs during sEPSCs. We measured sEPSCs before and after increasing spillover with TBOA. An example of sEPSCs recorded at -60 and $+40 \mathrm{mV}$ is shown before and after application of TBOA (Fig. $4 A$ ). In the presence of TBOA, the frequency of spontaneous events was often too high to make measurements of single events practical, perhaps because of upstream effects on glutamate uptake at the ON bipolar-AII amacrine cell synapse. We therefore measured the $Q-V$ relation of sEPSCs (i.e., the charge transfer, rather than current amplitude of the sEPSCs) at $-60,0$, and $40 \mathrm{mV}$ (Fig. 4B). sEPSCs strongly rectified (Fig. $4 B, C$; $\mathrm{RI}=0.17 \pm$ $0.06, n=4)$, indicating activation of primarily CP-AMPARs. As predicted by results from light-evoked EPSCs, the addition of TBOA recruited activation of CI-AMPAR, indicated by an increase in the RI to $0.89 \pm 0.03(n=4, p<0.05)$.

\section{Discussion}

By measuring the activation of $\mathrm{CP}$ AMPARs and CI-AMPARs at different light intensities, we find an even greater level of synaptic organization at ON RGCs synapses than previously appreciated. These receptors are functionally organized such that dim light signals arising in the primary rod pathway activate $\mathrm{CP}$ AMPARs almost exclusively, while stronger flashes carried by secondary rod pathways recruit CI-AMPARs.

These results could in theory be accounted for by either of two models. In Model 1, (Fig. 4D), both types of AMPARs are expressed at the same synapse, opposite a cone bipolar cell that receives rod input via gap junctions from AII amacrine cells. Here, a single type of ON cone bipolar cell would activate both CP-AMPARs and CI-AMPARs. A candidate cell would be the cone bipolar type 6 , which is thought to provide $\sim 75 \%$ or more of the synaptic input to $\alpha$ ON RGCs (Schwartz et al., 2012)

In the second model, AMPARs are segregated at separate synapses, and at least two classes of ON cone bipolar cell are required to activate CP-AMPARs and CI-AMPARs. In this scenario, CP-AMPARs are preferentially expressed at synapses opposite cone bipolar cells that receive strong AII input. At least one other, or possibly multiple classes of ON cone bipolar cell, would avoid contact with AII amacrine cells, or perhaps make only weak contacts, collecting their input primarily from cones. In support of this model, AII amacrine cells selectively avoid specific classes of $\mathrm{ON}$ bipolar cell in cat and rabbit retina; in rat retina, the strength of coupling between AII amacrine and ON bipolar cell varies highly depending upon ON bipolar cell type (for review, see Demb and Singer, 2012). Both models are consistent with our finding that enhancing spillover with TBOA activates CI-AMPARs. In Model 1, spillover occurs within individual postsynaptic sites. In Model 2, glutamate released at synaptic sites that process primary rod pathway input and 
express primarily CP-AMAPRs would spill over to neighboring synapses that mediate secondary rod pathway input and express CI-AMPARs.

Spike responses in RGCs evoked by dim light are temporally very precise, suggesting that the efficacy in synaptic transmission in the rod pathway is high (Murphy and Rieke, 2006). Presynaptic mechanisms, including the high degree of convergence of rods onto rod bipolar cells (Tsukamoto et al., 2001), and AII amacrine cell coupling (Sterling et al., 1988) are thought to be important underlying mechanisms for this precision. However, the high fidelity of this pathway may result from the postsynaptic expression of CPAMPARs on ON RGCs. The large single channel conductance and rapid decay kinetics of CP-AMPARs has been shown in cerebellar stellate cells to affect the probability of action potential firing (Savtchouk and Liu, 2011; Liu and Savtchouk, 2012). In RGCs these properties may increase synaptic gain and temporal fidelity of rod pathway responses. CP-AMPARs are expressed at several synaptic connections in early stages of the auditory pathway (Trussell, 1999; Gardner et al., 2001), suggesting that the expression of this type of AMPA receptor might be a common feature of sensory transmission.

\section{References}

Altimus CM, Güler AD, Alam NM, Arman AC, Prusky GT, Sampath AP, Hattar S (2010) Rod photoreceptors drive circadian photoentrainment across a wide range of light intensities. Nat Neurosci 13:1107-1112. CrossRef Medline

Chang B, Dacey MS, Hawes NL, Hitchcock PF, Milam AH, Atmaca-Sonmez P, Nusinowitz S, Heckenlively JR (2006) Cone photoreceptor function loss-3, a novel mouse model of achromatopsia due to a mutation in Gnat2. Invest Ophthalmol Vis Sci 47:5017-5021. CrossRef Medline

Chen S, Diamond JS (2002) Synaptically released glutamate activates extrasynaptic NMDA receptors on cells in the ganglion cell layer of rat retina. J Neurosci 22:2165-2173. Medline

Deans MR, Volgyi B, Goodenough DA, Bloomfield SA, Paul DL (2002) Connexin36 is essential for transmission of rod-mediated visual signals in the mammalian retina. Neuron 36:703-712. CrossRef Medline

Demb JB, Singer JH (2012) Intrinsic properties and functional circuitry of the AII amacrine cell. Vis Neurosci 29:51-60. CrossRef Medline

Dingledine R, Borges K, Bowie D, Traynelis SF (1999) The glutamate receptor ion channels. Pharmacol Rev 51:7-61. Medline

Dunn FA, Rieke F (2008) Single-photon absorptions evoke synaptic depression in the retina to extend the operational range of rod vision. Neuron 57:894-904. CrossRef Medline

Dunn FA, Doan T, Sampath AP, Rieke F (2006) Controlling the gain of
Control

TBOA (10 $\mu \mathrm{m})$

B

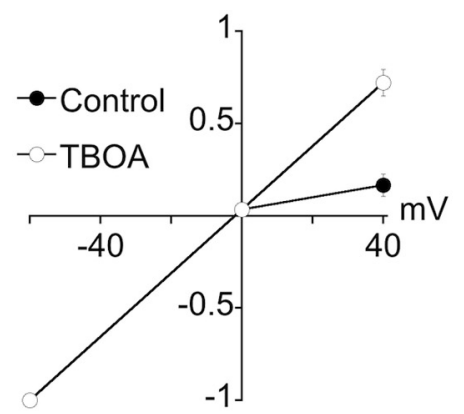

Normalized charge
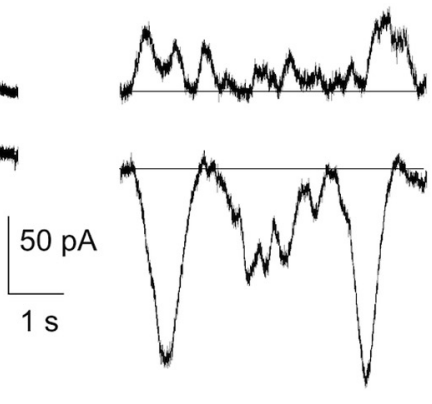

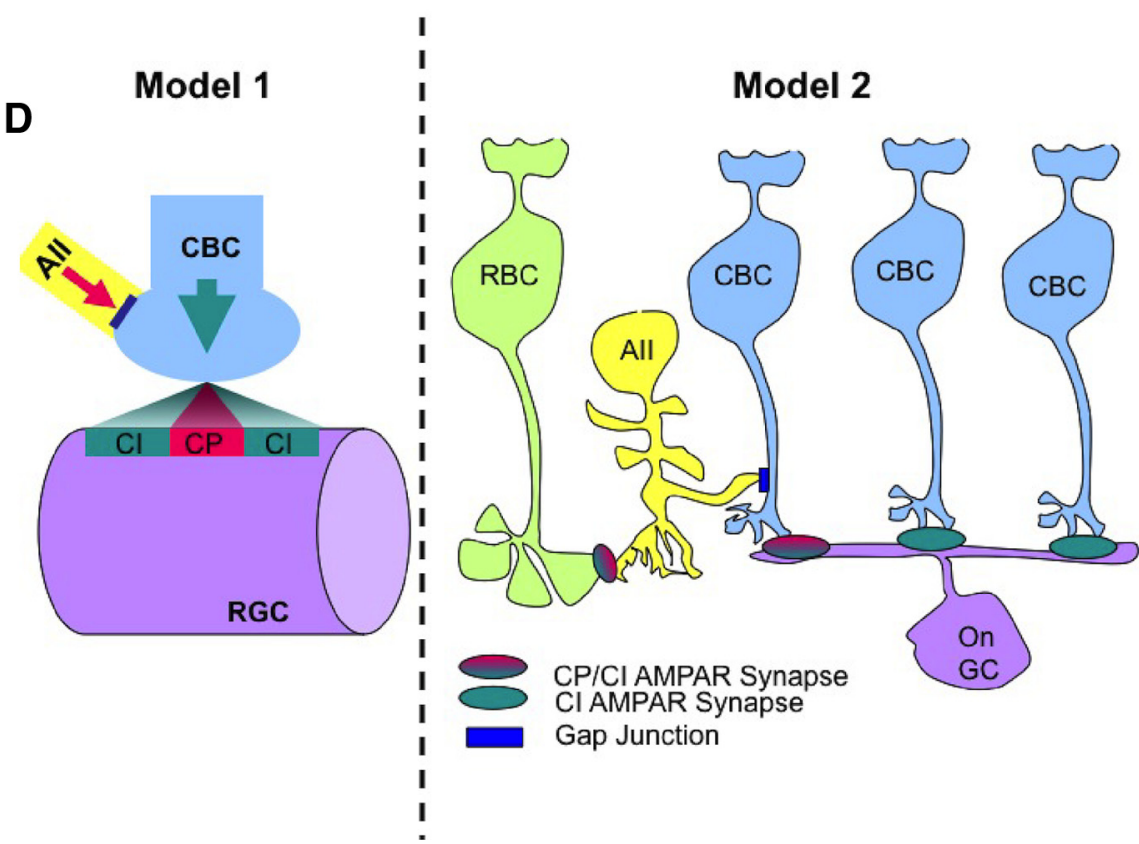

Figure 4. SEPSCs are mediated by (P-AMPARs. $A$, Representative recordings of spontaneous activity in $0 \mathrm{~N} \mathrm{RGCs}$ at +40 and $-60 \mathrm{mV}$ in control solution (left) and TBOA (right). The baseline for the records at -60 and $+40 \mathrm{mV}$ were fitted by eye (solid line). $B$, Average Q $-V$ plot ( $n=5$ cells) of the total charge transfer at $-60,0$, and $+40 \mathrm{mV}$, normalized to the charge transfer at -60 $\mathrm{mV}$. C, Comparison of RI values for charge transfer of sEPSCs in control and TBOA $\left(n=5\right.$; $\left.{ }^{* *} p<0.01\right)$. D. Two alternative models depicting the putative arrangement of CP-AMPARs and CI-AMPARs in ON RGCs. In the first, both types of AMPARs are expressed at the same synapse, but CP-AMPARs are closer to release sites. In the second, segregation of AMPARs is achieved primarily by expression at separate synapses. See text for details.

rod-mediated signals in the Mammalian retina. J Neurosci 26:39593970. CrossRef Medline

Field GD, Rieke F (2002) Mechanisms regulating variability of the single photon responses of mammalian rod photoreceptors. Neuron 35:733747. CrossRef Medline

Gardner SM, Trussell LO, Oertel D (2001) Correlation of AMPA receptor 
subunit composition with synaptic input in the mammalian cochlear nuclei. J Neurosci 21:7428-7437. Medline

Grünert U, Haverkamp S, Fletcher EL, Wässle H (2002) Synaptic distribution of ionotropic glutamate receptors in the inner plexiform layer of the primate retina. J Comp Neurol 447:138-151. CrossRef Medline

Jones RS, Carroll RC, Nawy S (2012) Light-induced plasticity of synaptic AMPA receptor composition in retinal ganglion cells. Neuron 75:467478. CrossRef Medline

Kolb H, Famiglietti EV (1974) Rod and cone pathways in the inner plexiform layer of cat retina. Science 186:47-49. CrossRef Medline

Lin B, Martin PR, Grünert U (2002) Expression and distribution of ionotropic glutamate receptor subunits on parasol ganglion cells in the primate retina. Vis Neurosci 19:453-465. Medline

Liu SJ, Savtchouk I (2012) Ca(2+) permeable AMPA receptors switch allegiances: mechanisms and consequences. J Physiol 590:13-20. Medline

Matsui K, Hosoi N, Tachibana M (1998) Excitatory synaptic transmission in the inner retina: paired recordings of bipolar cells and neurons of the ganglion cell layer. J Neurosci 18:4500-4510. Medline

Mills SL, Massey SC (1995) Differential properties of two gap junctional pathways made by AII amacrine cells. Nature 377:734-737. CrossRef Medline

Murphy GJ, Rieke F (2006) Network variability limits stimulus-evoked spike timing precision in retinal ganglion cells. Neuron 52:511-524. CrossRef Medline

Peng YW, Blackstone CD, Huganir RL, Yau KW (1995) Distribution of glutamate receptor subtypes in the vertebrate retina. Neuroscience 66:483497. CrossRef Medline

Qin P, Pourcho RG (1996) Distribution of AMPA-selective glutamate receptor subunits in the cat retina. Brain Res 710:303-307. CrossRef Medline

Qin P, Pourcho RG (1999) Localization of AMPA-selective glutamate receptor subunits in the cat retina: a light- and electron-microscopic study. Vis Neurosci 16:169-177. Medline

Sagdullaev BT, McCall MA, Lukasiewicz PD (2006) Presynaptic inhibition modulates spillover, creating distinct dynamic response ranges of sensory output. Neuron 50:923-935. CrossRef Medline

Savtchouk I, Liu SJ (2011) Remodeling of synaptic AMPA receptor subtype alters the probability and pattern of action potential firing. J Neurosci 31:501-511. CrossRef Medline

Schwartz GW, Okawa H, Dunn FA, Morgan JL, Kerschensteiner D, Wong RO, Rieke F (2012) The spatial structure of a nonlinear receptive field. Nat Neurosci 15:1572-1580. CrossRef Medline

Shimamoto K, Lebrun B, Yasuda-Kamatani Y, Sakaitani M, Shigeri Y, Yu- moto N, Nakajima T (1998) DL-threo-beta-benzyloxyaspartate, a potent blocker of excitatory amino acid transporters. Mol Pharmacol 53: 195-201. Medline

Smith RG, Freed MA, Sterling P (1986) Microcircuitry of the dark-adapted cat retina: functional architecture of the rod-cone network. J Neurosci 6:3505-3517. Medline

Sterling P, Freed MA, Smith RG (1988) Architecture of rod and cone circuits to the on-beta ganglion cell. J Neurosci 8:623-642. Medline

Strettoi E, Dacheux RF, Raviola E (1990) Synaptic connections of rod bipolar cells in the inner plexiform layer of the rabbit retina. J Comp Neurol 295:449-466. CrossRef Medline

Taschenberger H, Engert F, Grantyn R (1995) Synaptic current kinetics in a solely AMPA-receptor-operated glutamatergic synapse formed by rat retinal ganglion neurons. J Neurophysiol 74:1123-1136. Medline

Taylor WR, Chen E, Copenhagen DR (1995) Characterization of spontaneous excitatory synaptic currents in salamander retinal ganglion cells. J Physiol 486:207-221. Medline

Tian N, Hwang TN, Copenhagen DR (1998) Analysis of excitatory and inhibitory spontaneous synaptic activity in mouse retinal ganglion cells. J Neurophysiol 80:1327-1340. Medline

Trussell LO (1999) Synaptic mechanisms for coding timing in auditory neurons. Annu Rev Physiol 61:477-496. CrossRef Medline

Tsukamoto Y, Morigiwa K, Ueda M, Sterling P (2001) Microcircuits for night vision in mouse retina. J Neurosci 21:8616-8623. Medline

Völgyi B, Deans MR, Paul DL, Bloomfield SA (2004) Convergence and segregation of the multiple rod pathways in mammalian retina. J Neurosci 24:11182-11192. CrossRef Medline

Wang YV, Weick M, Demb JB (2011) Spectral and temporal sensitivity of cone-mediated responses in mouse retinal ganglion cells. J Neurosci 31: 7670-7681. CrossRef Medline

Wässle H, Boycott BB (1991) Functional architecture of the mammalian retina. Physiol Rev 71:447-480. Medline

Xia Y, Carroll RC, Nawy S (2006) State-dependent AMPA receptor trafficking in the mammalian retina. J Neurosci 26:5028-5036. CrossRef Medline

Xia Y, Nawy S, Carroll RC (2007) Activity-dependent synaptic plasticity in retinal ganglion cells. J Neurosci 27:12221-12229. CrossRef Medline

Zhang J, Diamond JS (2006) Distinct perisynaptic and synaptic localization of NMDA and AMPA receptors on ganglion cells in rat retina. J Comp Neurol 498:810-820. CrossRef Medline

Zhang J, Diamond JS (2009) Subunit- and pathway-specific localization of NMDA receptors and scaffolding proteins at ganglion cell synapses in rat retina. J Neurosci 29:4274-4286. CrossRef Medline 